\title{
Representation of Teacher in Andrea Hirata's Novel Guru Aini: A Study of Literary Psychology
}

\author{
${ }^{1}$ Evi Chamalah*, ${ }^{2}$ Reni Nuryyati, ${ }^{3}$ S.T. Nurbaya \\ ${ }^{1}$ Universitas Islam Sultan Agung, ${ }^{2}$ Universitas Gadjah Mada, \\ ${ }^{3}$ Universitas Negeri Yogyakarta \\ Received: \\ 4 December 2020 \\ Revised: \\ 21 December 2020 \\ Accepted: \\ 31 December 2020 \\ Published: \\ 31 December 2020
}

\author{
*Corresponding Author
}

Email: chamalah@unissula.ac.id

\begin{abstract}
Novel is one of literary works that is quite enjoyed by people. Novel has an important position in describing the reality of life through its storylines. One of them is Guru Aini novel by Andrea Hirata. The novel, which was just published in 2020, told about a teacher who worked in a remote island in Indonesia. The author's view of the teacher as an educator who could be represented by this literary work is constructed in a novel. Based on this, the study aimed to determine the representation of teachers in the Guru Aini novel by Andrea Hirata. The analysis in the research was conducted through the dimensions of literary psychology. The analysis in this study focused on the role of the teacher as an educator in a literary work. The results in this study indicated that the teacher in the novel Guru Aini by Andrea Hirata was represented in a positively charged construction. In this study, it was found that several teacher representations appeared in the novel, namely the representation of the teacher as an individual status, the representation of the teacher as the status of the teaching force, the representation of the teacher as an educator in the community, the representation of the psychological condition of the teacher, and the representation of the teacher's personality in the novel Guru Aini. by Andrea Hirata.
\end{abstract}

Keywords: representation; teacher; Guru Aini's novel

\section{INTRODUCTION}

Education is one of key factors in determining quality of human resource. The key of success in Indonesia education cannot be separated from the role of teachers as educators. What government have done to improve teachers' quality in education field have become inevitable topic to discuss each year. It is because the topic about teachers as educators attracts much public attention. Problems of teacher and education often arises in such writings in mass media or literary works. One of those is novel. Novel is a long fictional prose with characters and events arranged to deliver a story (Sudjiman, 1984). In contrast to Sudjiman, Nurgiyantoro (2009) suggested that novel is a quite long fictional prose, not too long but not too short. In addition, Saini (1986) indicated that novel is a literary work in form of prose. Other expert such as Kosasih (20120) said that novel is an imaginative work about life problematic. Based on some of the expert opinions above, the novel can be concluded as a prose essay about life with the characteristics and characteristics of the story. In line with this, Nurgiyantoro (2009) said that a novel is a fictional work offers a model of life that is narrated through its various intrinsic elements. These elements are what make a story in a novel feel like it really happens as if it 
were real life. This is what the author deliberately made by imitating and analyzing the real world complete with the events and settings built into the story. In this novel, the author's idealism arises in seeing the problems that exist in the world.

Problems arised in the novel are such kind of social phenomena hapening in real life. The phenomena could be certainly seen by watching and observing events in real life. The author turns the social phenomena into a narration through creative process until it becomes a novel. From the psychological point of view, the novel contains a life fulfilled with human behaviour in a social sphere. This is what Siswantoro (2005) had ever said that a novel is a form of literary work in which events and behaviors are experienced and carried out on purpose by humans. One of the social phenomena often recorded in literary works such as novels is the issue of education. This phenomenon is closely related to the problems that are present in educators such as teachers and the surrounding educational environment. Of course, this is not something that cannot be ignored by an author. The teacher as an important element of education will certainly influence various other elements such as students, curriculum, and the delivery of learning in schools.

In simple term, teacher is a kind of profession aiming to educate students at an educational level. Usman (2011) suggested that teacher is a profession or position that requires a special expertise in the field of education. Moreover, Mulyasa (2007) also suggested that teacher is an educator who could be an example for students and others. Based on these two opinions, it could be concluded that teacher is a profession that could be an example for people as this profession requires a special expertise in the field of education. It indicates that a teacher has a high quality standard among society.

Nowadays, teachers are still underestimated by people. he teaching profession is even considered a less promising profession. This was appointed by a writer named Andrea Hirata. Andrea Hirata raised this social phenomenon into a literary work entitled Guru Aini. The novel tells about the journey of a mathematics teacher who devotes herself to a school in marginal region in Indonesia (Hirata 2020).

Novel as a literary work is a kind of appreciation from author to life reality and a representation of author idealism as an individual and as part of society. The reality implied in literary or non-literary text would produce a representation reflected in the text. Goldin (2002) indicated that representation is a kind that describes or represents something in certain way. In line with previous opinion, Rosengrant et al. (2007) said that a representation becomes a representation symbolizing a certain object or process in a certain situation. Based on both opinions, the conclusion is that a representation is a kind of description to represent or symbolize a certain object in a certain situation.

This study will examine the representation of teachers in literary works with a literary psychology approach. Literary psychology is an approach used by some experts to understand a literary work. Wellek dan Warren (1995) in their book revealted that literary psychology can include the study of the psychology of the author as an individual, the study of creative processes in literary works, the study of psychological law applied in a literary work, or the impact of literature on readers. In simple terms, literary psychology can understand the relationship between psychology and literature to understand the psychological elements of writers, characters in literary works, or readers' psychology.

Researches on novel representation have been conducted by several experts. One of them is a research conducted by Armis et al (2015) entitled "Representasi Tokoh Lisa dalam Novel Buda Lisa Karya Jombang Santani Khairen: Kajian Psikologi Wanita. (Representation of Lisa in Buda Lisa Novel by Jombang Santani Khairen: A Study of Woman Psychology)" The study 
focused on representation of women in family and society. The study discussed about the role of women in society based on actions, speech, and behaviour of the woman character in the novel. Another research is the one conducted by Sari and Nuryatin (2017) entitled "Representasi Perempuan Bali dalam Novel-Novel Karya Oka Rusmini (Representation of Balinese Woman in Novels by Oka Rusmini)." The study was about representation of Balinese women through the Balinese woman character in the novels by Oka Rusmini. The third research is the one conducted by Farida and Eggy (2019) entitled "Representasi Kesenjangan Sosial-Ekonomi Masyarakat Pesisir dengan Perkotaan dalam Novel Gadis Pantai Karya Pramodya Ananta Toer (Representation of Socio-Economic Disparity Between Coastal and Urban Society in Gadis Pantai Novel by Pramoedya Ananta Toer)" The study was about representation of socioeconomic disparity between coastal and urban society as reflected in Gadis Pantai novel by Pramoedya Ananta Toer. Studies on novel representation are quite diverse but the one discussed about a character representation with literary psychology specifically in scientific studies is still in a low number. Furthermore, the author of this research was encouraged to study how the representation of teacher is in Guru Aini novel through literary psychology approach that could reflect educational and social values in a literary work. Purpose of this research is to determine the representation of a teacher as an individual, as an educator, as teacher in society, and also representation of teacher psychological condition, and representation of teacher personality in Guru Aini novel by Andrea Hirata.

\section{METHOD}

Research method is a way used by the researcher to collect facts or truth based on a particular discipline (Depdiknas, 2008). Akbar and Usman (2009) suggested that research method is a kind of procedure to reveal things based on systematic stages in sequence.

\section{Type of Research Method}

Research method used in this study was descriptive qualitative method. Sugiyono (2015) suggested that qualitative study is a study based on the philosophy of post-positivism. This study used the method to describe the teachers' views in Guru Aini novel in order to reflect an analysis about representation of teacher in the novel. In line with Sugiyono, Sukmadinata (2012) said that a descriptive qualitative research is a qualitative study to determine social phenomena and makes the researcher as the key instrument. Data in this study is in forms of words, clauses, and sentences in Guru Aini novel by Andrea Hirata. The data source of the study was Guru Aini novel by Andrea Hirata published by Bentang Pustaka in 2020 within 336 pages.

\section{Research Procedures}

This study used several research procedures. On the first stage, the author conducted an inventory of data collection. On the second stage, the author conducted data classification based on the classification that had been made previously. On the third stage, the author conducted an analysis on the clasified data. On the fourth stage, the author conducted discussion and conclusion drawing. Moreover, the author compiled a report of research result in the final stage.

\section{Data Collection Techniques}

The author collected data for this study by reading the Guru Aini novel and taking notes. The reading technique was conducted by reading the Guru Aini novel carefully to gain complete understanding about the content of the novel. The author also performed note-taking technique to record important things in the novel. Things that were noted by the author were those related to representation of teacher in the novel. 


\section{Data Validity}

Validity is a standard in an accuracy measurement. Sudjana (2004) revealed that validity is an accuracy of research instrument that could represent the assessed concepts. In addition, Moleong (1990) stated that validity is a validity of the data. In order to check the validity in this study, the author performed data triangulation based on the data collected preveiously. Triangulation was performed to check the validity of data by using other things related to the data. Theory triangulation was performed by using theories to discuss the representation of teacher in Guru Aini novel by Andrea Hirata.

\section{RESULTS AND DISCUSSION}

\section{Representation of Teacher in Guru Aini as an Individual}

Guru Aini novel by Andrea Hirata tells a story about a teacher named Guru Desi. She is a stranger who was appointed by the government to teach mathematics in Kampung Ketumbi. There are other teachers besides Guru Desi in the novel named Bu Afifah, Pak Syaifulloh, Kepala Sekolah Abnu, Guru Tabah, and Guru Laila. These five teachers are side characters in Guru Aini novel. The main character in the novel is Guru Desi. She is a reflection of a teacher who has high idealism, gets most respects from students, wise personality, gives much attention to children education, and takes a good care of her students' future. It is, of course, in contrary with other character in the novel.

Guru Desi is a teacher with a high confidence, strong principle, applicable visions and goals in learning, strong will for what to achieve, and dignity as an educator. For Guru Desi, self esteem should be upheld by being discipline and firm in everything. Although Guru Desi had raised in stable family, she is never arrogant and always stands by principles.

In Guru Aini novel, some representations of teacher as an individual revealed in the character of Guru Desi. Representation of teacher as an individual could be seen in some aspects. The following is a description of individual status as revealed in Guru Desi.

\section{Aspect of Commitment}

In commitment aspect, Guru Desi firmly stands by a principle that she will not buy new shoes until she finds a student who could be taught very well. The student should be good in mathematics. Guru Desi's commitment revealed in the following excerpt.

Untuk Desi berjanji pada dirinya sendiri, dia mengangkat semacam sumpah sepatu, bahwa dia akan terus memakai sepatu olahraga pemberian ayahnya sampai anak genius matematika itu ditemukan (Guru Aini, 2020: 50)

Desi promised herself, such kind of shoe vow, that she would always wear the sport shoes her father given to her until she found the mathematics genius (Guru Aini, 2020:50)

The excerpt indicated that Guru Desi firmly stands by her own commitment until she finds a boy student who is clever under her good care. Unfortunately, the boy could not afford to continue his education at school and chose to sell books in a store. The not-buying-new-shoes commitment continued as Guru Desi found her second student named Aini. After Aini succeeded, Guru Desi replaced her old shoes with new ones. 


\begin{abstract}
"Menggelegar halilintar di siang bolong, Guru Desi! Mendidih air dingin di dalam gelas! Gerangan apa yang terjadi sehingga Guru Desi mengganti sepatu legendaris Guru itu?" tanya Kepala Sekolah Abnu Kolidin, B.A. (Guru Aini, 2020: 230)

"A thunderous lightning in afternoon, Guru Desi! Cold water boils in a glass! What the heck happened that Guru Desi replaces her legendary shoes?" asked Abnu Kolidin, B.A., The Headmaster (Guru Aini, 2020: 230)
\end{abstract}

Based on the previous excerpts, the novel author described Guru Desi as a teacher with commitment. Guru Desi was the one who was so tough although many people contempted on her old shoes. With firm commitment and strong will, Guru Desi believed that someday she would buy new shoes to replace the old ones. Finally, she found the student she had looked for.

\title{
Aspect of Self Esteem
}

Representation of teacher as a personal in Guru Aini novel revealed in self esteem aspect. Guru Desi as a mathematics teacher had a high self esteem. It revealed in the folowing excerpt.

Di dalam kelas yang kuwalikan sendiri ada murid yang dapat nilai 2,5. Itulah nilai tertingginya lebih dari setahun ini. Lalu akn mendapat penghargaan sebagai guru terbaik? (Guru Aini 2020, 165)

In a class which I'm in charge, there was a student got 2,5. That was his best score more than a year. Then, I will be awarded as the best teacher? (Guru Aini, 2020: 165)

The excerpt reveald that Guru Desi had been awarded as the examplary teacher. However, Guru Desi felt it was inappropriate to get the award and returned it to the local department. Guru Desi felt that this award did not need to be given to him. Guru Desi was oriented that their hard work and dedication to students at school is not only to obtain the title of exemplary teacher. But rather educating students in Ketumbi village so that students can get a better life in the future.

By rejecting the award, Guru Desi showed that his sacrifice so far in Ketumbi Village was not just to get an award and promotion. However, Guru Desi wants to improve the lives of the Ketumbi people through education. The self-esteem aspect of Guru Desi appears in his self-confidence and conviction to continue to dedicate himself to the world of education. Desi teacher neglects things beyond his responsibility in educating the children of Ketumbi Village.

\section{Aspect of Dignity}

Guru Desi as a mathematics teacher in Guru Aini novel by Andrea Hirata had a fairly high dignity. It is because Guru Desi was decribed as a clever and firm teacher in each learning. The firm and discipline performed by Guru Desi led to her dignity in front of students, teachers and people of Ketumbi. Besides, the intelligence and skill always impressed students while Guru Desi was delivering mathematics. The dignity and charisma revealed in the following excerpt:

Maka mereka yang tak kuat mental bisa merasa ngap-ngap jika berada di dekat Guru Desi. Karena perasaan mereka bercampur aduk antara kagum pada kecantikan dan kecerdasannya, salut pada keputusan yang diambil seorang perempuan baru menginjak usia 18 tahun... (Guru Aini, 2020:46) 
So those who had weak mentality could lose his breath near Guru Desi. It is because they will get their feeling mixed of flatter on her beauty and intelligence, and salute to a decision a 18-year-old woman takes... (Guru Aini, 2020: 46)

The excerpt described Guru Desi as a teacher with dignity as she got much respect and impression from others. A teacher like Guru Desi finally became an example for students in Ketumbi. Besides her beauty, Guru Desi reflected that a teacher should be smart and clever to distribute knowledge to students at school.

\section{Representation of Teacher in Guru Aini Novel as an Educator}

Guru Desi as the main character in Guru Aini novel by Andrea Hirata is a teacher with educator status in a Senior High School in Ketumbi Village. Through the novel, Andrea Hirata represented the status of educator as the one to be example for others. It revealed implicitly in some aspects that the author deliberately emphasized in the stories. The following is the description of aspects revealed in Guru Aini novel as representaion of teacher as an educator.

\section{Sense of Responsibility}

Guru Desi as an educator had a highly sense of responsibility. It revealed in the novel that Guru Desi had never be late to school. Besides, she always conducted evaluation in form of written tests regularly to determine the students' understanding on the materials delivered. The following is an excerpt from the novel showing how responsible Guru Desi was as an educator.

\footnotetext{
"Pendidikan adalah soal murid-murid, Pak. Ada otoritas pendidikan, ada sekolah-sekolah, ada guru-guru, dan semua itu ada karena murid. Murid-murid harus dinomorsatukan. Delapan puluh persen murid sekolah ini, hampir seribu jumlahnya, punya nilai ulangan matematika rata rata di bawah 6." (Guru Aini, 2020:165)

"Education is about students, Sir. The existence of education authority, schools, teachers, and all of these are because of students. The students should be prioritized. Eighty percent of students in this school, almost a thousand, collected scores below 6." (Guru Aini, 2020: 165)
}

The excerpt indicated that Guru Desi always paid attention to her students' development. It shows a very good sense of responsibility had been conducted as an educator. The author attempted to represent the status of teacher as an educator that a teacher not only transfers knowledge but also experiences to the students. However, teacher as an educator had a responsibility on student development and how students receive materials during the learning at school.

The author represented a teacher as an educator should have highly sense of responsibility to conduct learning very well. Besides, a teacher with highly sense of responsibility should conduct the tasks well to gain the desired result.

\section{Competence}

As an educator, a teacher should have sufficient competence. The competence here means an ability or skill a teacher should have to deliver knowledge well to students. In Guru Aini novel, Guru Desi as mathematics teacher was represented as the one who had sufficient competence. The intelligence she had was considered capable of teaching mathematics well. Below is an excerpt indicated thet Guru Desi had a fairly good competence. 


\begin{abstract}
"Matematika harus diajar seorang ahli, Pak! Seorang yang bersertifikat resmi sebagai pengajar matematika seperti Guru Desi!” (Guru Aini, 2020:158)
\end{abstract}

"Mathematics should be taught by an expert, Sir! The one who officially certified as mathematics teacher just like Guru Desi!" (Guru Aini, 2020: 158)

Based on the excerpt, Guru Desi as the main character considerably had a good competence. The competence revealed in Guru Desi's background of education as a bachelor in mathematics. Graduating from Mathematics major of a university, Guru Desi also taught mathematics subject. Her knowledge and experience in field of mathematics had become an example that a teacher should have a competence in line with the field she belongs to. By this condition, the learning she conducted at school run very well. On the other hand, if the teacher did not have competence in line with the field, the learning would not run well. Students would be difficult to receive materials.

\title{
Accountability
}

The third aspect revealed in Guru Desi character was accountability. The accountability here means a responsibility and concern for the process and result of learning. The accountability aspect appears explicitly in Guru Aini novel through the behaviour during the learning. The following is an example of accountability aspect revealed in Guru Aini novel as reflected in Guru Desi character.

Akhirnya Guru Desi datang. Yang dilakukannya pertama adalah membagikan buku ulangan matematika itu. (Guru Aini, 2020: 147)

Finally Guru Desi is coming. First thing she did was distributing mathematics exam books. (Guru Aini, 2020: 147)

The excerpt indicated that Guru Desi always conducted evaluation regularly by conducting tests in certain period of time. Guru Desi conducted assessment on the result of the tests and shared it on the next day. Character of Guru Desi implicitly had the aspect of accountability in learning activities. She had responsibility and concern on the process and result of the mathematics learning. In this case, the author represented that a teacher as an educator should be able to conduct the aspect of accountability as a sense of resposibility and concern on the students.

\section{Representation of Teacher as Educator around Society}

Guru Desi as the main character had a special place for people of Ketumbi. The people considered Guru Desi as an example for society and students in Ketumbi Senior High School. People acknowledgement did not appear explicitly, but they highly put respect on Guru Desi for her intelligence and bravery. The folowing is an excerpt indicating that Ketumbi people give some respect on Guru Desi.

Hatinya kembali berbunga-bunga karena sepanjang jalan orang-orang yang tak dikenalnya kembali memanggilnya Bu Guru (Guru Aini, 2020: 36).

Her heart blooms as people she did not recognize called her Bu Guru along the street (Guru Aini, 2020: 36)

The excerpt indicated that Guru Desi as a stranger in Ketumbi Village did not need a long time to have a special place in people's heart. People of Ketumbi called her as $\mathrm{Bu}$ Guru along the street of Ketumbi village, although they had not know her personally. Not only in the beginning of her coming, but also for years of her existence 
in Ketumbi village, the people put their respect on her as an example. The following excerpt is an example that Guru Desi still gained respect even after a long time in Ketumbi Village.

Mereka tahu, meskipun aneh dan ganjil penampilannya, Bu Desi jauh, jauh lebih cerdas dari mereka. (Guru Aini, 2020:48).

They knew, though it was strange on her appearance, Mrs. Desi was far more intelligent than anyone. (Guru Aini, 2020: 48)

Guru Desi appearance with her identical shoes that never be replaced is one of interesting things. Certainly many people talked about it. However, no one dared to address it. Her beauty and intelligence were something above anything else.

\section{Representation of Teacher Psychological Condition in Guru Aini Novel}

In Guru Aini novel by Andrea Hirata, based on Maslow theory, Guru Desi had identical character of human potency as the one who fully developed herself in form of self actualization. Representation of teacher psychological condition revealed in some aspects of psychology in the character of Guru Desi. Guru Desi as the main character became one alternative chosen by the author to represent psychological condition owned by teacher as an educator. The following is a description about representation of teacher psychological condition in Guru Aini novel by Andrea Hirata.

\section{High Dedication}

Guru Desi was a teacher with high dedication on the job assigned to her. Dedication in this case revealed in her strong will to keep teaching in a remote vilage in Sumatra. Based on the skill and competence, Guru Desi actually could become a successful teacher and could earn much money outside of Ketumbi Vilage. However, her high dedication in education and occupation as a teacher made her prefer to keep teaching in Ketumbi Village.

Setelah bertahun tahun bertugas sebenarnya dia bisa mengusulkan untuk dipindah tugas ke luar kota yang lebih besar namun dia menolak kemudahan itu. (Guru Aini, 2020: 52).

After years of assignment, she could propose to reassignment to other bigger cities but she refused the ease. (Guru Aini, 2020: 52)

The excerpt indicated that Guru Desi actually could propose reassignment from Ketumbi Village to other cities in Sumatra. The regulation said that every civil servant could propose reassignment after certain period of time. However. Guru Desi was not a teacher in common. Her dedication in education led her to keep teaching in a remote region.

\section{Having Concern for Children}

Another psychological condition revealed on the main character in Guru Aini novel by Andrea Hirata was a concern for students. The concern was described in the opening of free-tuition school for children in Ketumbi Village. The following is an excerpt indicating that Guru Desi is a figure with a good concern for children in Ketumbi Village.

"Kurasa setelah keberhasilanmu, akan banyak murid datang untuk belajar, Aini. Punya sekolah matematika gratis, pro bono, adalah impianku sejak dulu, Boi!” kata Guru sambil tersenyum. (Guru Aini, 2020: 228) 
"I think after your success, there will be students to study, Aini. Having a free-tuition school, pro bono, has been my dream, Boi!" said the teacher smiling (Guru Aini, 2020: 228)

The excerpt indicated that Guru Desi had long wanted a free school for children in Ketumbi Village. Guru Desi wanted children there to be clever in mathematics and to change their way of thinking for a better future. The free school was a proof that Guru Desi was a figure who had concern for children in Ketumbi Village, especially those who studied in Ketumbi Senior High School.

\section{Creative}

A good teacher is the one who could create an interesting and joyful learning acitivy. That is also what Guru Desi had done as a mathematics teacher. Mathematics has been such an enemy for many children in Ketumbi Village. To encourage them studying mathematics well is a big challenge for a teacher. The following is an example of how creative Guru Desi was as revealed in Guru Aini novel by Andrea Hirata.

Tanpa diketahui Aini, Guru Desi pun menggigit jarinya karena geram tak kunjung menemukan cara untuk mengajari muridnya itu. Dicobanya berbagai macam metode pengajaran matematika, tak ada yang berhasil. (Guru Aini, 2020:178).

Without Aini's awareness, Guru Desi bite her fingers as she was furious for not finding ways to teach students. She attempted several teaching methods, none was successful. (Guru Aini, 2020: 178)

Guru Desi was a teacher who was able to attempt several methods of mathematics teaching for Aini who was difficult to understand mathematics. Nevertheless, efforts from Guru Desi to teach mathematics with several methods was a proof of her creativity as a teacher. It was not an easy thing for sure. Mathematics is too difficult to modify with different methods for students to undestand.

Moreover, Guru Desi also provided other methods to decrease students' hesitation and anxiety. The following is an excerpt indicating that Guru Desi provided creative ways to overcome hesitation and anxiety inside of Aini.

Karena dia ingin berhasil meniti jembatan kayu kecil itu hingga ke seberang. Lebih dari segalanya, karena dia tahu dengan cara itulah Guru Desi melatihnya untuk mengatasi keraguan dan ketakutan. (Guru Aini, 2020: 249)

Since she wanted to succeed to walk across a tiny wooden bridge. More than everything, as she knew that Guru Desi had taught her by this way to control her hesitation and anxiety (Guru Aini, 2020: 249)

The previous excerpt indicating that Aini was one of Guru Desi's students who was told to walk on a bridge with closed eyes to overcome her hesitation and anxiety. In this case, Guru Desi provided other methods in learning to train students to control their hesitation and anxiety on mathematics.

\section{Appreciative}

Guru Desi as a discipline mathematics teacher always conducted evaluations of each learning activity. In the evaluation, the learning outcome was in form of scores 1-10. Guru Desi as a teacher was always appreciative to her students based on the scores they collected.

“Mantap, Boi!” begitu pujian khasnya. (Guru Aini, 2020: 147) 
“Selamat Aini! Kaulah kampiun baru matematika itu!” (Guru Aini, 2020:222)

"Good job, Boi!" she took compliment. (Guru Aini, 2020: 147)

"Congratulation, Aini! You are the new mathematics champion!" (Guru Aini, 2020: 222)

Both excerpts indicated that Guru Desi loved to compliment her students who were good in mathematics. Besides, those who were not good enough in mathematics also gained compliment for showing improvement in learning outcome. The improvement that Guru Desi wanted was not such a magical improvement that led them gained perfect score. However, the compliment was given only to those who indicated significant improvement by his own effort and thinking process. Guru Desi often performed this kind of appreciative attitude during the learning.

\section{Representation of Teacher Personality in Guru Aini Novel}

The character of Guru Desi in Guru Aini novel by Andrea Hirata indicated a social status as an educator. The author named the main character by attaching profession and the original name as one name in the whole story. The author deliberately created a profile of a teacher by how he named the character in the novel. The character of Guru Desi had such correlation between the name and profession attached to it.

In Guru Aini novel, all the teachers did not have high status in economy. Teachers in the novel were described as ones who were always humble and had high dignity while conducting a learning. Behaviour and character in the novel could represent good and bad attitudes from the characters in Guru Aini novel. The dominance of positive attitude revealed in the teachers' attitude and sayings, especially from Guru Desi. The character of Guru Desi represented an ideal teacher in providing knowledge to students at school. The minor of Guru Desi's character was only on how she could not control her anger, but it happened only in few parts. Guru Desi as a teacher was good in competence, firm, and clever to conduct some learning techniques for her students as narrated by the author as an ideal teacher in the novel.

\section{CONCLUSION}

Representation of teacher in Guru Aini novel by Andrea Hirata fully indicated several kinds of psychological condition. Main character of the novel as a mathematics teacher named Guru Desi had several psychological condition based on views underlying the characters' thought in living their life. In this study, the research revealed some representations of teacher in the Guru Aini novel by Andrea Hirata; representation of teacher as an individual, representation of teacher as an educator, representation of teacher as an educator in society, representation of teacher psychological condition, and representation of teacher personality.

Representation of teacher in Guru Aini novel as an individual revealed in some aspects; Guru Desi' commitment, self esteem and dignity. Meanwhile, representation of teacher as an educator revealed in some aspects such as responsibility, competence and accountability. Moreover, representation of teacher as an educator in society revealed in how people in the village put respect on Guru Desi and made her as an example. representation of teacher psychological condition revealed in the main character, Guru Desi, such as high dedication, concern for children, creativity and being appreciative. 
Personality of an ideal teacher was also represented by the main character, Guru Desi, through the dominance of her positive attitude and behaviour. Guru Desi as a teacher was very good in competence, assertive, and clever to conduct learning technique for her students as narrated by the author as an ideal teacher in the novel.

\section{REFERENCES}

Akbar, P.S., \& Usman, H. (2009). Social Research Methods. Jakarta: Bumi Aksara.

Armis, M. et al. (2015). Representation of Lisa in Bunda Lisa Novel by Jombang Santani Khairen: A Study of Woman Psychology. Jurnal Publika Budaya, 3 (1), 34-45.

Depdiknas. (2008). Regulation of Indonesia Republic Govenment No.19, 2005 about National Education Standard.. Jakarta: Depdiknas.

Farida, N., \& Andalas, E. F. (2019). Representation of Socio-Economic Disparity Between Coastal and Urban Society in Gadis Pantai Novel by Pramodya Ananta Toer. Jurnal Kembara, 5(1), 74-90.

Goldin, A.G. (2002). Representation in Mathematical Learning and Problem Solving. English, L.D (Ed) .Handbook of International Research in Mathematics Education,197- 21. Mahwah NJ: Laurence Erlbaum.

Hirata, A. (2020). Guru Aini. Yogyakarta: Bentang Pustaka.

Kosasih. (2012). Basics in Literary Skills. Bandung: Yrama Widya.

Moleong, L. J. (1990). Qualitative Research Method. Bandung: Remaja Rosdakarya.

Mulyasa, E. (2007). Becoming Professional Teacher: Creating Creative and Enjoyable Learning. Bandung: PT Remaja Rosdakarya.

Nurgiyantoro, B. (2009). Studies of Fiction Theories. Yogyakarta: Gadjah. Mada University Press.

Nurgiyantoro, B. (2007). Studies of Fiction Theories. Yogyakarta: Gadjah. Mada University Press.

Rosengrant, D., E. E. and AV. Heuvelen. (2007). “An Overview of Recent Research on Multiple Representations".Rutgers, The State University of New Jersey GSE, 10 Seminary Place, New Brunswick NJ, 08904

Saini, K.M., \& Sumarjo, J. (1986). Literary Appreciation. Jakarta: Gramedia.

Sari, S. P., \& Nuryatin, A.. (2017). Representation of Balinese Woman in Novels by Oka Rusmini. Jurnal Pendidikan Bahasa dan Sastra Indonesia. 2(2), 44-48.

Siswantoro. (2005). Methods in Literary Research: Psychological Analysis. Surakarta: Universitas Muhammadiyah Surakarta.

Sudjana, N. (2004). Assessment on Result of Teaching-Learning Activity. Bandung: Remaja Rosdakarya.

Sudjiman, P. (1984). Dictionary of Literary Terms. Jakarta: PT Gramedia. 
Journal of Advanced Multidisciplinary Research

Vol. 1, No. 2, 2020, pp. 121-132

ISSN: 2723-6978

http://jurnal.unissula.ac.id/index.php/JAMR

DOI: http://dx.doi.org/10.30659/JAMR.1.2.121-132

Sugiyono. (2015). Methods in Educational Research (Quantitative, Qualitative and R\&D). Penerbit CV. Alfabeta: Bandung.

Sukmadinata, N. S. (2012). Methods in Educational Research. Bandung: PT Remaja Rosdakarya.

Usman, M. U. (2011). Becoming Professional Teacher. Bandung: PT Remaja Rosdakarya.

Wellek, R., \& Warren, A. (1995). Theories in Literature (translated by Budianta). Jakarta: Gramedia. 

ERROR: syntaxerror

OFFENDING COMMAND: --nostringval--

\section{STACK :}

/ Title

()

/ Subject

(D:20210109233604+07'00')

/ModDate

()

/Keywords

(PDFCreator Version 0.9.5)

/Creator

(D:20210109233604+07'00')

/CreationDate

(Aril)

/Author

-mark- 